\title{
APPLICATION OF THE NEW OROSLIPPERY TECHNOLOGY IN THE PREPARATION OF ENTERIC SLIPPERY COATED TABLET OF NAPROXEN
}

\author{
NIDHAL K. MARAIE, ANAS T. ALHAMDANY, ZAINAB H. MAHDI \\ Department of Pharmaceutics, College of Pharmacy, Al-Mustansiriyah University, Baghdad, Iraq \\ Email: pharm.dr.nidhal.khazaal@unomustansiriyah.edu.iq
}

Received: 24 Mar 2017 Revised and Accepted: 09 May 2017

\section{ABSTRACT}

Objective: The aim of this study was to formulate enteric coated oroslippery tablets (OSTs) of naproxen to overcome the common problems of stomach irritation and swallowing difficulties which accompanied the administration of naproxen tablets.

Methods: Different formulas of enteric slippery tablets were prepared by direct compression method. Various parameters were investigated like the effect of eudragit L-100 (eud.) concentration (as an enteric polymer), coating level and effect of different concentrations of croscarmellose sodium CCS (as super disintegrant) on the physical properties. Finally, in an in vitro disintegration and release study was carried out.

Results: The enteric slippery optimal formula (F8) was selected to consist of double coat (17.5\% eudragit (eud.)) with core tablet containing (6\% CCS). It was found that this optimal formula having an acceptable physical property (friability, hardness, thickness and weight variation). Besides, the best acid resistant potential represented by the protection of the OSTs for $2 \mathrm{~h} \mathrm{in} 0.1 \mathrm{~N} \mathrm{HCl}$ without any sign of disintegration and drug release. Moreover, it was found that (F8) has a disintegration time equal to $(8 \pm 1.36 \mathrm{~min})$ and release of $80 \%(20 \pm 0.18 \mathrm{~min})$ in phosphate buffer pH 6.8 .

Conclusion: The result revealed the successful preparation of naproxen tablets using enteric slippery coating that can be easily swallowed and prevent direct irritation of the stomach with acceptable tablet weight.

Keywords: Naproxen, Oroslippery technology, Enteric slippery coated tablet, Eudragit L-100

(C) 2017 The Authors. Published by Innovare Academic Sciences Pvt Ltd. This is an open access article under the CC BY license (http://creativecommons.org/licenses/by/4.0/] DOI: http://dx.doi.org/10.22159/ijpps.2017v9i6.18676

\section{INTRODUCTION}

Dysphagia or swallowing difficulties is a common problem in tablet dosage form affecting about $50 \%$ of the population [1], representing the major limitation of the most commonly used tablets [2, 3]. For this reason, many patients do not take their medications as prescribed, which results in a high incidence of noncompliance and ineffective therapy [4].

Consequently, different tablet dosage forms were developed to overcome swallowing difficulties, in which drugs are administered orally without the need for chewing or prior dispersion or dissolution in water in order to produce a systemic effect [5]. Recently, a new tablet dosage form oroslippery tablet (OSTs) was developed in our previous publication to overcome dysphagia and to alleviate some disadvantages of the traditional tablet, through hydrating it in the oral cavity and offering easily slipperiness of the intact tablet with good taste masking effect in the mouth without the need of water [6]

Naproxen is a propionic acid derivative. It belongs to a group of nonsteroidal anti-inflammatory drugs (NSAIDs) that have analgesic anti-inflammatory and antipyretic properties, through inhibiting the enzyme cyclooxygenase (COX-1) that might causes GIT irritation [7]. Enteric-coated tablets were designed to pass unchanged through the stomach to the intestine where they disintegrate to allow drug dissolution and absorption to give its therapeutic effect and widely employed when the drug is irritating the gastric mucosa [8].
This work is a developed application of new easily swallowed oroslippery enteric coated tablet for naproxen with good taste masking property that may be used as an alternative to conventional uncoated naproxen tablet.

\section{MATERIALS AND METHODS}

\section{Materials}

Naproxen, croscarmellose sodium (CCS), sodium saccharin, polyethene glycol 6000 (PEG 6000) and eudragit L-100 (eud.) (Samara drug industry, Iraq). Mannitol and magnesium stearate (Mg stearate) (Provizer pharma, India). Crospovidone (CP) (Aladdin chemistry, China). Xanthan gum (xan.), peppermint oil, red iron oxide, talc and titanium dioxide (Himedia, India). All other chemicals, solutions and reagents used were of analytical grade.

\section{Methods}

\section{Preparation of naproxen core tablets}

Naproxen core tablets were formulated by direct compression using $11 \mathrm{~mm}$ punch and die set, using the ingredients in (table 1). The preweighed amounts of all excipients (except Mg stearate) were mixed together for about $10 \mathrm{~min}$, followed by additional $5 \mathrm{~min}$ mixing after addition of $\mathrm{Mg}$ stearate [9]. These core tablets were prepared using three different concentrations of $\operatorname{CCS}(2 \%, 4 \%$ and $6 \%)$ to demonstrate their effect on the disintegration and release of naproxen from the prepared tablets.

Table 1: Composition of the prepared naproxen core tablets

\begin{tabular}{llll}
\hline Ingredients & C1 & C2 & \\
\hline Naproxen & 250 & 250 & 250 \\
CCS & 8 & 16 & 24 \\
Mannitol & 138 & 130 & 122 \\
Mg stearate & 4 & 4 & 4 \\
Total weight & 400 & 400 & 400 \\
\hline
\end{tabular}

All quantities are expressed in mg 


\section{Preparation of the enteric slippery coat}

Three different enteric slippery coating formulas (table 2) were prepared. This is achieved by the following steps:

\section{$1^{\text {st }}$ step: preparation of the enteric polymer solution}

Eudragit L-100 (eud.) (Enteric polymer) was added gradually in three different concentrations $(13.5 \%, 15.5 \%$ and $17.5 \%)$ to a distilled water containing $1 \mathrm{~N}$ sodium hydroxide $(\mathrm{NaOH})$ and mixed together at room temperature using magnetic stirrer at $1000 \mathrm{rpm}$ for about 10 min until a lump free solution obtained.

\section{$2^{\text {nd }}$ step: preparation of the pigment dispersion}

This was prepared by dissolving sodium saccharin (as sweetening agent) in distilled water then followed by the addition of PEG 6000 (as plasticizer) and mixing for about $10 \mathrm{~min}$ in magnetic stirrer at
$1400 \mathrm{rpm}$ at room temperature, after that the pigment (red iron oxide), the opacifier (titanium dioxide) and the anti-adherent (talc) were added and mixed for another $10 \mathrm{~min}$.

\section{3d step: preparation of the xanthan gum mixture}

Xanthan gum (xan.) as slipperiness inducing agent $[10,11]$, was added to the previously heated distilled water $\left(39{ }^{\circ} \mathrm{C}\right)$ and homogenized using magnetic stirrer at $600 \mathrm{rpm}$ for about $5 \mathrm{~min}$.

\section{$4^{\text {th }}$ step: preparation of the enteric slippery coating}

The final slippery enteric coating was prepared by adding the filtered pigment dispersion to the enteric polymer solution and mixing for about $10 \mathrm{~min}$ at $400 \mathrm{rpm}$, followed by its addition onto the xanthan gum mixture along with the peppermint oil (flavouring agent) which further homogenized for $10 \mathrm{~min}$ at $400 \mathrm{rpm}$ at room temperature.

Table 2: Composition of the enteric slippery coat (in w/w \%)

\begin{tabular}{llll}
\hline Ingredients & $\mathrm{T} 1$ & $\mathrm{~T} 2$ & $\mathrm{~T} 3$ \\
\hline Eud. & $13.5 \%$ & $15.5 \%$ & $17.5 \%$ \\
$1 \mathrm{~N} \mathrm{NaOH}$ & $4 \%$ & $4 \%$ & $4 \%$ \\
Red iron oxide & $1 \%$ & $2 \%$ & $1 \%$ \\
Titanium dioxide & $2 \%$ & $2 \%$ & $2 \%$ \\
Talc & $2 \%$ & $0.3 \%$ & $2 \%$ \\
Xan. & $0.3 \%$ & $2.5 \%$ & $0.3 \%$ \\
Sodium Saccharin & $2.5 \%$ & $0.5 \%$ & $2.5 \%$ \\
Peppermint oil & $0.5 \%$ & $10 \%$ & $0.5 \%$ \\
PEG 6000 & $10 \%$ & Up to $100 \mathrm{ml}$ & $10 \%$ \\
Distilled water & Up to $100 \mathrm{ml}$ & & Up to $100 \mathrm{ml}$ \\
\hline
\end{tabular}

\section{Preparation of naproxen enteric-coated oroslippery tablets}

Eight different enteric coated OSTs of naproxen were prepared (table 3 ) by dipping the core tablet $\left(\mathrm{C}_{1}\right)$ in each of the enteric slippery coating solutions $\left(\mathrm{T}_{1}, \mathrm{~T}_{2}\right.$ or $\left.\mathrm{T}_{3}\right)$ once referred as $\left(\mathrm{C}_{1} \mathrm{~T}_{1}, \mathrm{C}_{1} \mathrm{~T}_{2}\right.$ and $\left.\mathrm{C}_{1} \mathrm{~T}_{3}\right)$, and double referred as $\left(\mathrm{C}_{1} \mathrm{~T}_{1}^{2}, \mathrm{C}_{1} \mathrm{~T}_{2}^{2}\right.$ and $\left.\mathrm{C}_{1} \mathrm{~T}_{3}{ }^{2}\right)$ in formulas
(F1-F6) to study the effect of eudragit concentration and coating level. The best eudragit concentration and coating level where used to prepare formulas (F7 and F8) containing different concentrations of CCS in their core tablets $\left(\mathrm{C}_{2}\right.$ and $\left.\mathrm{C}_{3}\right)$ with double coating level in $\mathrm{T}_{3}$ coating solution and referred as $\mathrm{C}_{2} \mathrm{~T}_{3}{ }^{2}$ (F7) and $\mathrm{C}_{3} \mathrm{~T}_{3}{ }^{2}$ (F8). The dipping process was then followed by drying at $60^{\circ} \mathrm{C}$ for $5 \mathrm{~min}$.

Table 3: Composition of naproxen enteric-coated OSTs

\begin{tabular}{ll}
\hline Naproxen enteric coated OSTs & Composition \\
\hline F1 & $\mathrm{C}_{1} \mathrm{~T}_{1}$ \\
F2 & $\mathrm{C}_{1} \mathrm{~T}_{1}{ }^{2}$ \\
F3 & $\mathrm{C}_{1} \mathrm{~T}_{2}$ \\
F4 & $\mathrm{C}_{1} \mathrm{~T}_{2}{ }^{2}$ \\
F5 & $\mathrm{C}_{1} \mathrm{~T}_{3}$ \\
F6 & $\mathrm{C}_{1} \mathrm{~T}_{3}{ }^{2}$ \\
F7 & $\mathrm{C}_{2} \mathrm{~T}_{3}{ }^{2}$ \\
F8 & $\mathrm{C}_{3} \mathrm{~T}_{3}{ }^{2}$ \\
\hline
\end{tabular}

\section{Pre-compressibility evaluation for the core tablet powder}

The flowability of the core tablet powder was evaluated by measuring carr's or compressibility index, Hausner's ratio and angle of repose. The first two parameters were evaluated by the calculation of the bulk and tap densities $[12,13]$, while the latter was measured by the fixed base method [3].

\section{Post-compressibility evaluation}

\section{Physical properties}

The physical properties of the prepared core and coated tablets were evaluated, where the weight variation and friability were studied according to the USP requirements, while the hardness and thickness were estimated using electrical hardness tester and vernier caliper respectively [14-16].

\section{Disintegration test}

This test was performed (according to the USP specification) for the enteric coated slippery tablet in $0.1 \mathrm{~N} \mathrm{HCl}$ for $2 \mathrm{~h}$, where no sign of disintegration should be observed then followed in phosphate buffer pH 6.8 and record the time for complete disintegration $[12,17]$.

\section{Dissolution test}

Drug release profile for the enteric coated oroslippery tablets was evaluated in vitro using dissolution apparatus type II. According to the USP the dissolution test was performed at $37^{\circ} \mathrm{C}$ where the percent drug release should not exceed $10 \%$ of the labeled amount after $2 \mathrm{~h}$ in $0.1 \mathrm{~N} \mathrm{HCl}$ and not be less than $80 \%$ after $45 \mathrm{~min}$ in phosphate buffer $\mathrm{pH}$ $6.8[12,18,19]$.

Five milliliter samples were withdrawn each time and analyzed by UVvisible spectrophotometer at wave length of $330 \mathrm{~nm}$. The test was done in triplicate and the average value was compared by using the percent drug released in $2 \mathrm{~h}\left(\% \mathrm{D}_{2} \mathrm{~h}\right)$ and the time required to reach $80 \%$ release $\left(\mathrm{T}_{80 \%}\right)$.

\section{Variables affecting drug release}

The following variables were studied to optimize the enteric coated slippery tablets: 


\section{Effect of eudragit L-100 concentration}

Formulas F1, F3, F5 (mono-coated) and formulas F2, F4, F6 (doublecoated) were prepared using different concentration of eud. (13.5\%, $15.5 \%$ and $17.5 \% \mathrm{w} / \mathrm{w}$ ) respectively to demonstrate its effect on the release of naproxen from the prepared tablets.

\section{Effect of coating level}

The effect of coating layer was shown in formulas (F1-F6) were mono and double coating level was performed using $\mathrm{T}_{1}-\mathrm{T}_{3}$ coating solution on $\mathrm{C}_{1}$ core tablet to see its effect on the release of naproxen from the prepared tablets.

\section{Effect of superdisintegrant concentration}

The effect of CCS concentration on drug release from the prepared tablets was studied using (F6-F8) containing 8, 16 and $24 \mathrm{mg}$ CCS respectively.

\section{Content uniformity test}

The optimum formula $\mathrm{F} 8 \quad\left(\mathrm{C}_{3} \mathrm{~T}_{3}{ }^{2}\right)$ was subjected to content uniformity test, by crushing a randomly selected 10 tablets individually and dissolving them in methanol, the solution was filtered and assayed for naproxen content using UVvisiblespectrophotometer at wave length of $330 \mathrm{~nm}$ [20].

\section{Drug excipient compatibility test}

The pure drug (naproxen) powder, core tablet $\left(\mathrm{C}_{3}\right)$ together with the optimum coated formula F8 (which were previously grinded into fine powder), were analysed by Fourier transform infrared spectroscopy (FT-IR) from (4000-400) $\mathrm{cm}^{-1}$ by using the presseddisk technique [21] in order to detect any physicochemical incompatibilities between the drug and different excipients.

\section{Statistical analysis test}

The results were expressed as mean \pm standard deviation, and were analysed using analysis of variance (ANOVA) single factor to compare the sample means and to determine the statistical significance, at which $(\mathrm{P}<0.05)$ was considered to be significant.

\section{RESULTS AND DISCUSSION}

Pre-compressibility and post-compressibility studies for the prepared core tablets and enteric-coated oroslippery tablets

Table 4 illustrates all pre-recompression parameters including angle of repose, Carr's index and Hausner ratio for the prepared core powder mixture $\left(\mathrm{C}_{1}-\mathrm{C}_{3}\right)$ for each formula, and its corresponding type of flow. These results clearly demonstrated that all core tablets formulas possessed an acceptable flow ability according to USP.

Table 4: Pre-compressibility results for the prepared core tablets

\begin{tabular}{llll}
\hline Formula & Angle of repose (degree) & Carr's index & Hausner ratio \\
\hline C1 & $32.24 \pm 1.30$ & $12.79 \pm 2.25$ & $1.17 \pm 0.05$ \\
C2 & $31.7 \pm 2.27$ & $11.75 \pm 2.05$ & $1.14 \pm 0.16$ \\
C3 & $29.14 \pm 1.05$ & $9.33 \pm 0.54$ & $1.11 \pm 0.50$ \\
\hline
\end{tabular}

(All results are expressed as mean $\pm \mathrm{SD}, \mathrm{n}=3$ )

In addition physical properties for the formulated core $\left(\mathrm{C}_{1}-\mathrm{C}_{3}\right)$ and enteric coated oroslippery tablets (F1-F8) were showed in (table 5 and 6) respectively. The results clearly demonstrated nonsignificant differences in the physical properties between the prepared core tablets (C1, C2, and C3). A significant improvement in the friability was observed after coating comparing to the core tablets, while non-significant reduction in the friability was observed between formulas F1, F3 and F5 (monolayer coat) in comparison to F2, F4, F6 (double layer coat) respectively that could be explained by the significant increase in the coated tablets weight with a non-significant increment in coat thickness after the application of double coat. Also, a non-significant increase in the coated tablet weight and thickness was detected between the mono coated formulas themselves (F1, F3, and F5) and also between the double coated formulas themselves (F2, F4, and F6) where different coating solution $T_{1}, T_{2}$ and $T_{3}$ used. This was attributed to the slight increase in the viscosity of the enteric coating formulas resulting from increasing eudragit L-100 concentration from $13.5 \%$ in (F1, F2) to $15.5 \%$ and $17.5 \%$ in (F3, F4) and (F5, F6) respectively, an effect which might increase the hydrodynamic drag during the dipping process [2224]. Furthermore, non-significant differences were observed in the hardness between the core and coated tablets and between the coated tablets themselves indicating that the enteric oroslippery coating formula had a negligible effect on the hardness.

Table 5: Physical properties for the formulated core tablets

\begin{tabular}{llll}
\hline Formula & Friability (\%) & Hardness $\mathbf{( k g / \mathbf { c m } ^ { 2 } )}$ & Thickness (mm) \\
\hline C1 & $0.64 \pm 0.01$ & $5.23 \pm 1.03$ & $5.42 \pm 1.34$ \\
C2 & $0.72 \pm 0.03$ & $5.67 \pm 1.21$ & $5.44 \pm 1.02$ \\
C3 & $0.66 \pm 0.05$ & $5.98 \pm 1.66$ & $5.43 \pm 1.33$ \\
\hline
\end{tabular}

(Results are expressed as mean $\pm \mathrm{SD}, \mathrm{n}=3$ )

Table 6: Physical properties for the enteric coated oroslippery tablets

\begin{tabular}{lllll}
\hline Formula & Friability (\%) & Hardness $\left.\mathbf{( k g} / \mathbf{c m}^{2}\right)$ & Thickness $(\mathbf{m m})$ & Weight variation (mg) \\
\hline F1 & $0.29 \pm 0.01$ & $5.73 \pm 1.10$ & $5.51 \pm 1.04$ & $436.2 \pm 1.56$ \\
F2 & $0.21 \pm 0.03$ & $5.43 \pm 1.01$ & $5.63 \pm 0.11$ & $454.1 \pm 2.13$ \\
F3 & $0.25 \pm 0.02$ & $5.65 \pm 1.03$ & $5.54 \pm 1.22$ & $437.5 \pm 1.06$ \\
F4 & $0.20 \pm 0.01$ & $5.93 \pm 1.00$ & $5.66 \pm 1.23$ & $455.2 \pm 1.35$ \\
F5 & $0.18 \pm 0.02$ & $5.21 \pm 0.91$ & $5.57 \pm 1.06$ & $438.2 \pm 2.45$ \\
F6 & $0.14 \pm 0.01$ & $5.54 \pm 0.23$ & $5.68 \pm 1.53$ & $456.7 \pm 1.08$ \\
F7 & $0.13 \pm 0.02$ & $5.89 \pm 1.23$ & $5.67 \pm 1.09$ & $457.4 \pm 2.33$ \\
F8 & $0.15 \pm 0.02$ & $5.36 \pm 1.01$ & $5.69 \pm 1.03$ & $456.6 \pm 1.56$ \\
\hline
\end{tabular}

(Results are expressed as mean $\pm \mathrm{SD}, \mathrm{n}=3$ ) 
In vitro disintegration test for the prepared enteric-coated oroslippery tablets

The results of In vitro disintegration of the prepared tablets were showed in (table 7). These results clearly demonstrate that after increasing eudragit L-100 amount by either the application of higher concentration of eud. or the application of double coating the formulas F1-F5 fails to pass the USP requirement of disintegration with the exception of F6 that remains intact for $2 \mathrm{~h}$ in $0.1 \mathrm{~N} \mathrm{HCl}$ but require a long time to disintegrate $(120 \mathrm{~min})$ in phosphate buffer $\mathrm{pH}$ 6.8. While a significant reduction in disintegration time in phosphate buffer was observed in formulas F7 and F8 were comparing with F6 due to the application of higher concentration of CCS in naproxen core tablets but with suitable protection from disintegration in acidic media and F8 gave the best result.

Table 7: In vitro disintegration time for the prepared naproxen enteric-coated oroslippery tablets

\begin{tabular}{lll}
\hline Formula & DT in min (in 0.1 N HCl) & DT in min (in phosphate buffer pH 6.8) \\
\hline F1 & $(-)^{*}$ & $(-)^{*}$ \\
F2 & $(-)^{*}$ & $(-)^{*}$ \\
F3 & $(-)^{*}$ & $(-)^{*}$ \\
F4 & $(-)^{*}$ & $(-)^{*}$ \\
F5 & $(-)^{*}$ & $(-)^{*}$ \\
F6 & intact tablet for 2 h & $120 \pm 1.09$ \\
F7 & intact tablet for 2 h & $17 \pm 0.76$ \\
F8 & intact tablet for 2 h & $8 \pm 1.36$ \\
\hline
\end{tabular}

(Results are expressed as mean $\pm \mathrm{SD}, \mathrm{n}=3$ ), ${ }^{*}$ where $(-)$ denotes to the beginning of disintegration in $0.1 \mathrm{~N} \mathrm{HCl}$

Table 8: In vitro release data for the prepared naproxen enteric-coated oroslippery tablets

\begin{tabular}{lll}
\hline Formula & $\mathbf{\%}_{\mathbf{~} \mathbf{~} \mathbf{~}}$ & $\mathbf{T}_{\mathbf{8 0}} \mathbf{( \mathbf { m i n } )}$ \\
\hline F1 & $20.09 \pm 0.56$ & More than 165 \\
F2 & $12.42 \pm 1.78$ & More than 165 \\
F3 & $13.68 \pm 2.76$ & More than 165 \\
F4 & $10.54 \pm 1.09$ & More than 165 \\
F5 & $2.45 \pm 2.96$ & More than 165 \\
F6 & 0 & More than 165 \\
F7 & 0 & $165 \pm 2.71$ \\
F8 & 0 & $140 \pm 1.05$ \\
\hline
\end{tabular}

(Results are expressed as mean \pm Standard deviation, $\mathrm{n}=3$ )

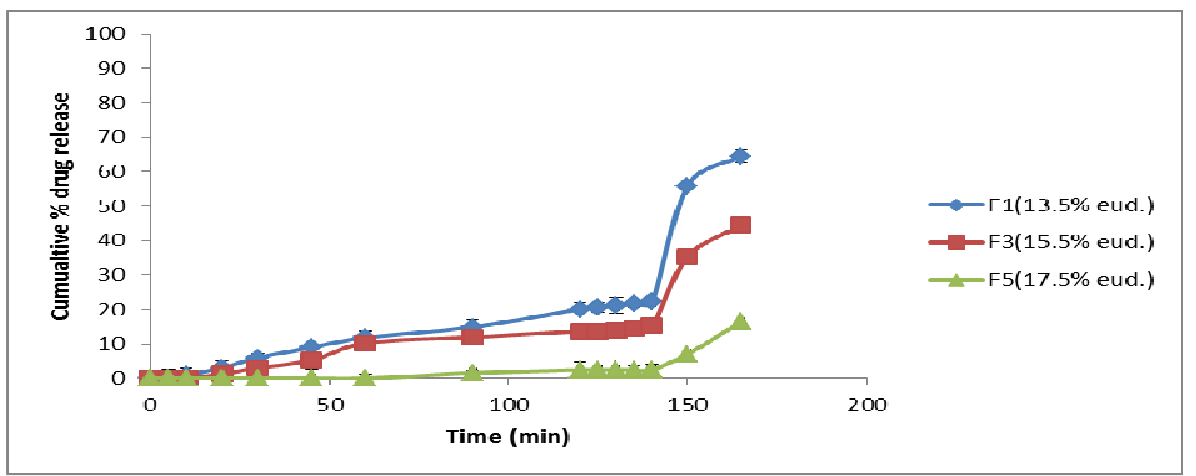

Fig. 1: Effect of eudragit L-100 concentration on the release of naproxen from monolayer enteric-coated oroslippery tablets (F1, F3, F5) in $(0.1 \mathrm{~N} \mathrm{HCl})$ for $2 \mathrm{~h}$ followed by their addition to (phosphate buffer $\mathrm{pH} 6.8$ ) for $45 \mathrm{~min}$, where all core tablets containing $2 \%$ CCS as super disintegrant (Error bars indicate mean $\pm \mathrm{SD}, \mathrm{n}=3$ )

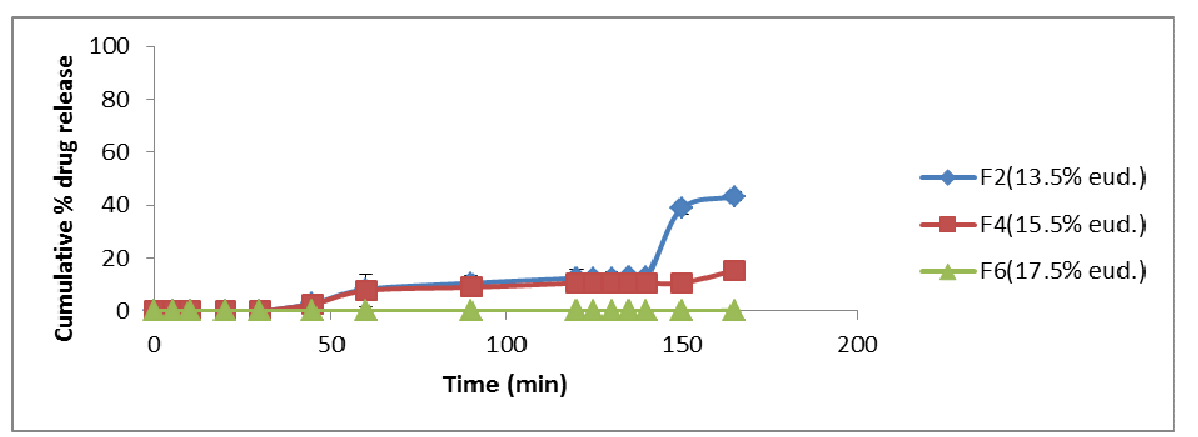

Fig. 2: Effect of eudragit L-100 concentration on the release of naproxen from double layer enteric-coated oroslippery tablets (F2, F4, F6) in ( $0.1 \mathrm{~N} \mathrm{HCl)}$ for $2 \mathrm{~h}$ followed by their addition to (phosphate buffer $\mathrm{pH} 6.8$ ) for $45 \mathrm{~min}$, where all core tablets containing $2 \%$ CCS as super disintegrant (Error bars indicate mean $\pm S D, n=3$ ) 


\section{Variables affecting drug release}

\section{Effect of eudragit L-100 concentration}

Results of In vitro release of naproxen from the enteric-coated OSTs are summarised in (table 8) and (fig. 1 and 2). Formulas from F1-F6 were formulated to show the effect of different concentrations of eudragit L-100 after application of mono-coating in (F1, F3, and F5) and double coating in (F2, F4, and F6) using the same core tablet containing $2 \%$ CCS. Increasing the concentration of eudragit L-100 from $13.5 \%$ in $\mathrm{F} 1$ and $\mathrm{F} 2$ to $15.5 \%$ in $\mathrm{F} 3$ and $\mathrm{F} 4$ and finally to $17.5 \%$ in F5 and F6; that were respectively mono and double coated with the enteric coating dispersion; causes a significant reduction in $\% \mathrm{D}_{2} \mathrm{~h}$ in $0.1 \mathrm{~N} \mathrm{HCl}$ and hence significantly increasing the acid resistance of the enteric coating due to the higher amount of eudragit L-100 [14], although all of these formulas fail to meet the requirement of USP in that they released more than $10 \%$ of the labeled amount in $2 \mathrm{~h}$ (Except F6) and all of them required more than $45 \mathrm{~min}$ in phosphate buffer $\mathrm{pH} 6.8$ to reach $80 \%$ release.

\section{Effect of coating level}

Results in (fig. 3-5) clearly demonstrate the effect of coating level on naproxen release from the prepared tablets. Increasing coating level in each eud. Concentration from mono coating to double coating in $(\mathrm{F} 1, \mathrm{~F} 2),(\mathrm{F} 3, \mathrm{~F} 4)$ and in $(\mathrm{F} 5, \mathrm{~F} 6)$ causes a significant reduction in the dissolution process represented by a significant reduction in $\% D_{2 h}$ in Formulas F1-F6. The best acid resistance in F6 where 0\% drug release after $2 \mathrm{~h}$, although all these formulas (F1-F6)required more than $45 \mathrm{~min}$ in phosphate buffer $\mathrm{pH} 6.8$ to reach $80 \%$ [12].

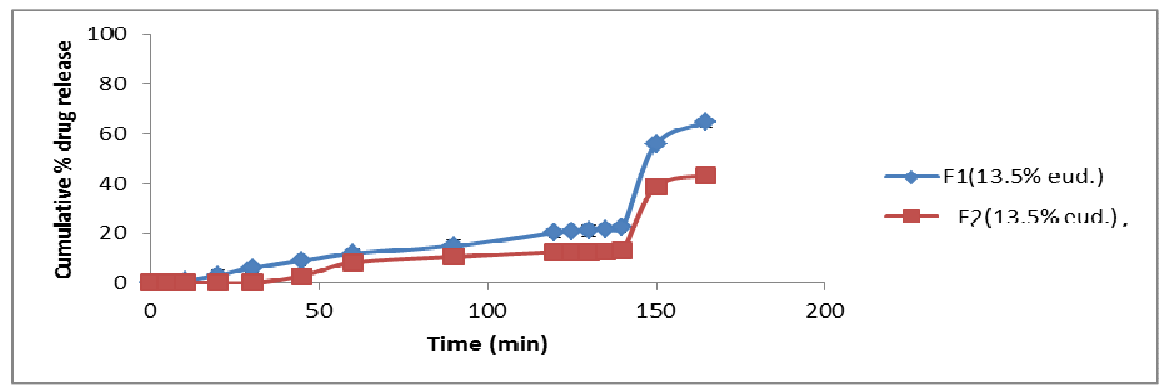

Fig. 3: Effect of coating level (with $13.5 \%$ eud.) on the release of naproxen from enteric-coated oroslippery tablets (F1 and F2) in (0.1N $\mathrm{HCl}$ ) for $2 \mathrm{~h}$ followed by their addition to (phosphate buffer $\mathrm{pH} \mathrm{6.8)} \mathrm{for} 45 \mathrm{~min}$, where all core tablets containing $2 \%$ CCS as super disintegrant (Error bars indicate mean $\pm S D, n=3$ )

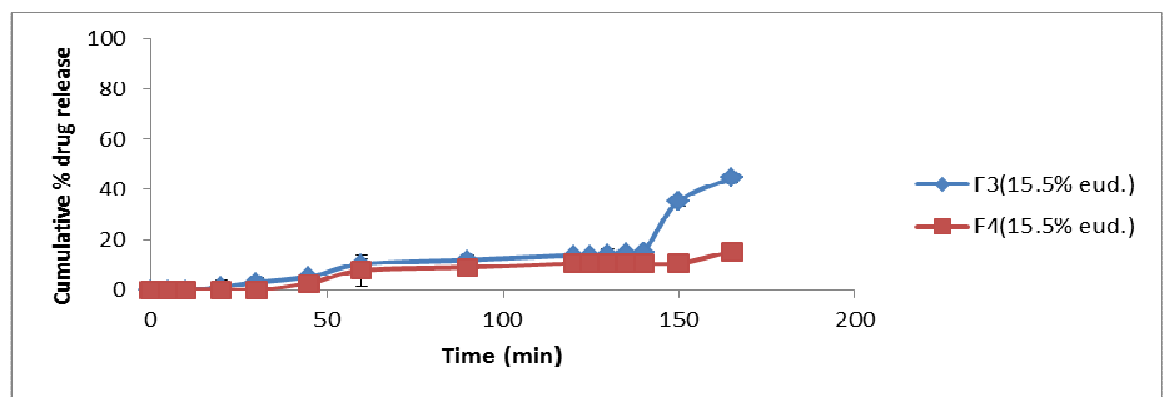

Fig. 4: Effect of coating level (with $15.5 \%$ eud.) on the release of naproxen from enteric-coated oroslippery tablets (F3 and F4) in (0.1N $\mathrm{HCl}$ ) for $2 \mathrm{~h}$ followed by their addition to (phosphate buffer $\mathrm{pH}$ 6.8) for $45 \mathrm{~min}$, where all core tablets containing $2 \%$ CCS as super disintegrant (Error bars indicate mean $\pm \mathrm{SD}, \mathrm{n}=3$ )

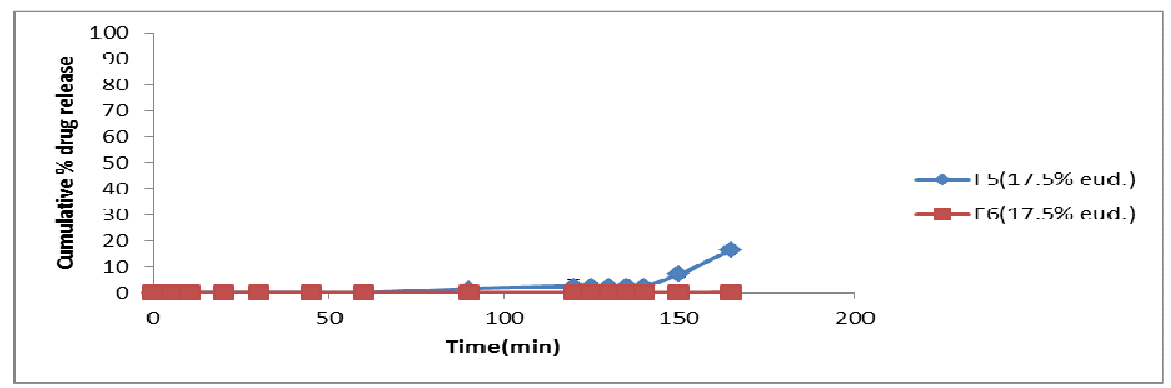

Fig. 5: Effect of coating level (with $17.5 \%$ eud.) on the release of naproxen from enteric-coated oroslippery tablets (F5 and F6) in (0.1N $\mathrm{HCl}$ ) for $2 \mathrm{~h}$ followed by their addition to (phosphate buffer pH 6.8) for $45 \mathrm{~min}$, where all core tablets containing $2 \%$ CCS as super disintegrant (Error bars indicate mean $\pm S D, n=3$ )

\section{Effect of superdisintergrant concentration}

The previous data clearly illustrated that all formulas (F1-F6) failed to pass the USP requirement for disintegration and release, with the exception of F6 which remains intact in acidic media but required a long time to disintegrate $(120 \mathrm{~min})$ in phosphate buffer $\mathrm{pH} 6.8$. Therefore, Formulas F7 and F8 were prepared using cores containing $2 \%$ and $4 \%$ of CCS as superdisintergrant.
The results in (fig. 6) demonstrated a significant acid resistance after $2 \mathrm{~h}$ in $0.1 \mathrm{~N} \mathrm{HCl}$, followed by a significant reduction in DT and $\mathrm{T}_{80 \%}$ in phosphate buffer $\mathrm{pH} 6.8$ resulting from the effect of CCS as a superdisintergrant which led to fast burst release of naproxen tablet once it is introduced in intestine [17]. For this reason F8 was selected as the optimum formula since it gave the best acid resistance with fast and high \% drug release in phosphate buffer pH 6.8. 


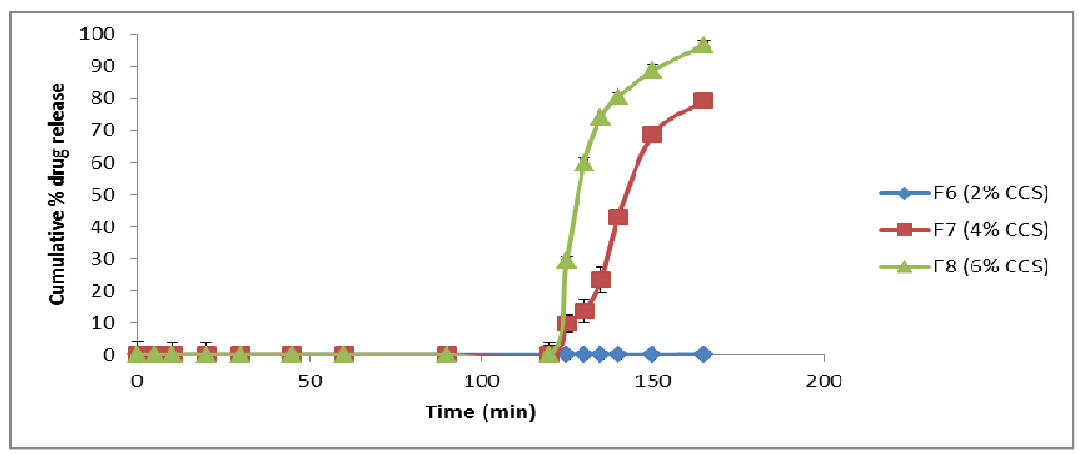

Fig. 6: Effect of different CCS concentration on the release of naproxen from enteric-coated oroslippery tablets in (0.1N $\mathrm{HCl})$ for $2 \mathrm{~h}$ followed by their addition to (PH 6.8 phosphate buffer) for $45 \mathrm{~min}$, where all formulas are double coated with $17.5 \%$ eudragitL-100 (Error bars indicate mean $\pm S D, n=3$ )

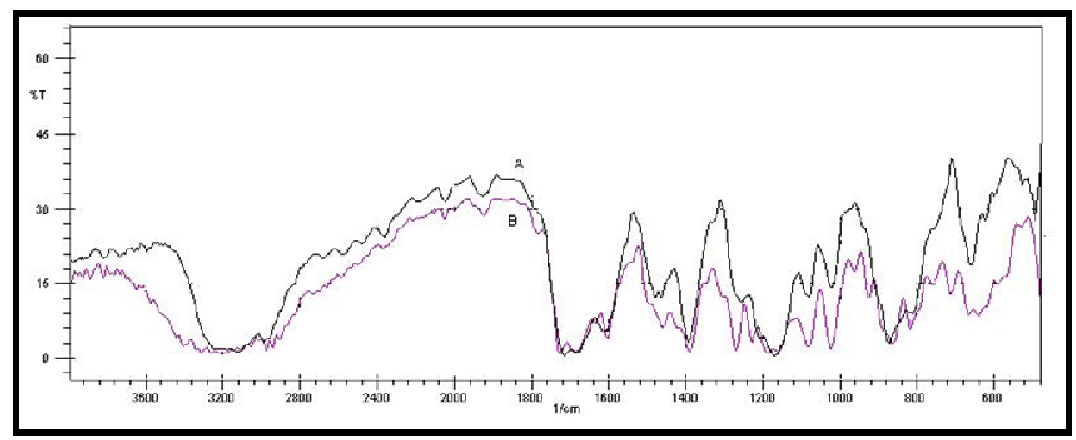

Fig. 7: FTIR spectrum of (A) naproxen and (B) F8

\section{Content uniformity}

The optimum naproxen enteric coated OSTs (F8) was complied with USP specification, as no tablet of the randomly selected ten tablets was outside the range (85-115\%), indicating the uniform distribution of naproxen in the prepared tablets.

\section{Drug excipient compatibility}

The FTIR spectrum of pure naproxen as showed in (fig. 7A) in addition to the selected core $\left(\mathrm{C}_{3}\right)$ together with the enteric coated OSTs represented (F8) as showed in (fig. 7B) has the same characteristic absorption bands of pure naproxen at the $\mathrm{C}=0$ stretching region, which are between (1600 and 1800) $\mathrm{cm}^{-1}[20]$, indicating that no interaction occurred between the drug and other components of the prepared OSTs.

\section{CONCLUSION}

In this study, preparation of enteric slippery coated tablets for naproxen showed that it can be readily swallowed (avoiding problems usually associated with tablet dosage forms). An improvement and high stability in disintegration or release properties were achieved after application of this new technology. It was successful to show that enteric oroslippery tablets for naproxen didn't dissolve or disintegrate in the stomach, but gave fast $100 \%$ release once it reaches to the intestine. Therefore, it can be concluded that application of a slippery coating technology in the preparation of enteric coated tablet for naproxen was a creative and has a great potential to be an effective approach for new delivery of drugs.

\section{ACKNOWLEDGMENT}

The authors would like to thank Al-Mustansiriyah University (www. uomustansiriyh. edu. iq) Baghdad-Iraq for its support in the present work.

\section{CONFLICT OF INTERESTS}

Declared none

\section{REFERENCES}

1. Fu Y, Yang S, Jeong SH, Kimura S, Park K. Orally fast disintegrating tablets: developments, technologies, taste-masking and clinical studies. Crit Rev Ther Drug Carr Syst 2004;21:433-75.

2. Roy A. Orodispersible tablets: a review. Asian J Pharm Clin Res 2016;9:19-26.

3. Gilbert SB, Neil RA. Tablets. In: Lachman L, Lieberman HA. The theory and practice of industrial pharmacy. Special Indian edition. India: CBS Publishing; 2009. p. 293-94.

4. Kelly J, D'Cruz G, Wright D. Patients with dysphagia: experiences of taking medication. J Adv Nurs 2009;66:82-91.

5. Patil R, Pande V, Sonawane R. Nano and microparticulate chitosan-based system for the formulation of carvedilol rapid melt tablet. Adv Pharm Bull 2014;5:1-10.

6. Mahdi ZH, Maraie NK. New easily swallowed tablets with slippery coating for the antihypertensive drug valsartan. UK J Pharm Biosci 2015;3:9-19.

7. Sweetman SC. Martindale the complete drug reference. $36^{\text {th }}$ ed. Vol. 1. China: Pharmaceutical Press publishing; 2009. p. 1152-89.

8. Loyd VA, Nicholas GP, Howard CA. editors. Ansels's pharmaceutical dosage forms and drug delivery systems. 9th ed. London: Wolters Kluwer, Lippincott Williams and Wilkins publishing; 2011. p. 225-56.

9. Omprakash B, Ajay S, Santosh G, Amin P. Formulation development of venlafaxine hydrochloride extended-release tablet and in vitro characterizations. Int J PharmTech Res 2012;4:1777-84.

10. Gulum S, Koksel F, Serpil S, Arzu B, Venkatesh M. Effect of xanthan and guar gums on quality and staling of gluten free cakes baked in microwave-infra red combination oven. Int J Food Sci Tech 2010;45:87-93.

11. Michael, Irene A. Hand book of green chemicals. $2^{\text {nd }}$ ed. USA: synaps information resource; 2004. p. 292. Available from: https://books.google.iq/books?isbn=1890595799. [Last accessed on 20 Feb 2017]. 
12. United States Pharmacopeia (USP 30) and the $25^{\text {th }}$ edition of the National Formulary (NF25) [Electronic copy]. USA: United States pharmacopeial convention publishing; 2007.

13. Sakarkar DM, Kshirsagar RV, Tadavi SA, Pawde PK. Tableting compression behaviour of enzyme trypsin-chymotrypsin. Int J Appl Pharm 2009;1:30-43.

14. Surya B, Singh R, Anshu S, Ayush G, Dharmendra SS Formulation and evaluation of enteric coated tablet of ilaprazole. Int Curr Pharm J 2013;2:126-30.

15. Pranav P, Anshu S, Chetan SC, Ravindra k. Preparation and evaluation of enteric-coated tablet of sodium valproate. Int J Res Pharm Chem 2013;3:583-90.

16. Farshid A, Rama B, Muralidharan G, Nargund LVG. Formulation and evaluation of orodispersible tablets of zolmitriptan. Asian J Pharm Clin Res 2014;7:127-34.

17. Rama B, Shalem RT, Grace R. Formulation development and evaluation of enteric coated tablets of rabeprazole sodium. J Pharm Biol Sci 2014;9:14-20.

18. Ajit P, Santosh P, John D. Formulation and evaluation of enteric coated tablets of azithromycin dehydrate. Int J ChemTech Res 2011;3;1479-84.

19. Kammela KC, Mohammad Y, Shahidulla S, Sai V, Vedavyas P. Formulation and evaluation of enteric coated pellets of omeprazole. Int J Drug Dev Res 2012;4:257-64.
20. Ngiik T, Amal AE. Effects of liquisolid formulations on dissolution of naproxen. Eur J Pharm Biopharm 2009;73:37384.

21. Silverstein RM, Webster FX, Kiemle D. editors. Spectrometric identification of organic compounds. 7th ed. USA: Wiley publishing; 2005.

22. Gill SH, Prausnitz MR. Coating formulations for microneedles. Pharm Res 2007;24:1369-80.

23. Fang HW, Li KY, Su TL, Yang TCK, Chang JS, Lin PL, et al. Dip coating assisted polylactic acid deposition on steel surface: film thickness affected by drag force and gravity. Materials Lett 2008;62:3739-41.

24. Yimsiri P, Mackley MR, Yimsiri P, Mackley MR. Spin and dip coating of light-emitting polymer solutions: matching experiment with modeling. Chem Eng Sci 2006;61:3496-505.

\section{How to cite this article}

- Nidhal K Maraie, Anas T Alhamdany, Zainab H Mahdi. Application of the new oroslippery technology in the preparation of enteric slippery coated tablet of naproxen. Int J Pharm Pharm Sci 2017;9(6):198-204. 